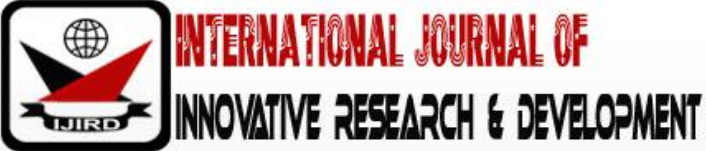

ISSN 2278-0211 (Online)

\section{Correlation between Environmental Variables and Rental Values of Residential Properties in Greater Port Harcourt City, Rivers State, Nigeria}

\author{
Obed-Ndukwu, Ihuoma, C. \\ Ph. D. Research Scholar, Institute of Geosciences and Space Technology (IGST), \\ Rivers State University, Nkpolu-Oroworukwo, Port Harcourt, Nigeria \\ Gobo, A.E \\ Professor, Department of Applied Meteorology and Environmental Management, \\ Rivers State University, Nkpolu-Oroworukwo, Port Harcourt, Nigeria
}

\begin{abstract}
:
Property value is a function of many factors. It is a common knowledge that environmental variables and the influence of location externalities are vital to the formation of residential property value. The study assesses the relationship between environmental variables and rental value of residential properties in Greater Port Harcourt City, Rivers State. Data was collected from both primary and secondary sources. In a wider perspective, data was collected through questionnaires, interviews, document reviews and field observations. A total of 450 out of 500 copies of questionnaires administered to the residents was retrieved while 78 was retrieved out of 116 copies of questionnaires administered to the Professional Estate Valuers managing residential properties within the study area. Questionnaire was distributed on the basis of household population in the study area and stratified systematic sampling approach was adopted in the selection of 500 (residents) respondents. Data analysis techniques used include mean, standard deviation and spearman rank correlation. Three research questions were formulated and one hypothesis tested at 0.01 and 0.05 level of significance. Findings revealed that there is a relationship between environmental variables and rental value of residential properties. Secondly, the study showed environmental variables that negatively influence residential property value include floodwater, air pollution, waste dumpsite, traffic congestion, noise pollution and wetland in the study area. Based on the findings, recommendations were made among which is the need for the creation of awareness and public sensitization on environmental issues with potential adverse effect on property values and living standard was also recommended. Essentially, the study will be beneficial to students, property developers, local planning authorities of Rivers State in regulating development and housing for the infrastructural development in the State.
\end{abstract}

Keywords: Correlation, environmental variables, rental value, residential properties

\section{Introduction}

Real property has no value if it has no utility, if it is not scarce and if it is not effectively demanded. Real property has significance only as it satisfies man's needs and desires. It is this man's collective desire for real property that gives rise to value (Olusegun, 2003). Thus, the ability of a property to satisfy man's needs and desires together with its degree of scarcity and utility compared with others makes man to ascribe value to it. Property value, therefore, according to Millington (1981) is the money obtainable from a person(s) willing and able to purchase property when it is offered for sale by a willing seller, allowing for reasonable time for negotiation and with the full knowledge of the nature and uses which the property is capable of being put.

Real property is a heterogeneous good that is comprised of a bundle of unique characteristics reflecting not only its location, but equally affected by other amenities such as the quality of neighbourhood and infrastructure. Ge and Du (2007) opine that property value is an essential aspect of property market worldwide and determined by a variety of factors and the determination of those factors is a significant part of property valuation.

Previous research has found out that the factors affecting residential property value depend on a number of variables because housing is a heterogeneous commodity. Ajibola, Olaniyan and Simon (2012), opines that factors that affects property values can be classified into property facility variables, environmental variables, neighborhood variables and accessibility variables.

Housing is a process which makes the act of dwelling possible. In effect, the term, housing includes the house itself and total surrounding environment with its ancillary facilities and services (Ayotamuno \& Owei, 2015). Nwuba, (2004) stated that the value of landed properties is influenced by several factors among which environmental variable stands to be prominent. 
The organization of land use is based on three criteria which include economic prosperity, quality of life and quality of environment. Therefore, the environment can strongly influence the real estate business. An obvious example is the impact of environmental amenities (open space or proximity to parks) or environmental disamenities (air pollution, water pollution, or proximity to noxious facilities) on housing prices through capitalization. When two housing units are identical in all respects except an environmental attribute, the unit with the preferred attribute (e.g., better air quality or greater proximity to the park) can be expected to sell for a higher price. That is, the value that individuals place on the improvement in the environmental attribute should get capitalized into the price of the house (Segerson, 2001).

Residential properties according to Leramo, (1992) are properties providing housing accommodation. According to AFRES (2017) "residential properties" are generally constructed to mean properties primarily acquired for residence"; it has the attribute of giving shelter, security, comfort, privacy, investment and personal identity. Rental value is the monetary return which may reasonably be expected to be obtained from letting a property in the Open Market at a particular point in time (Ekenta, 2010).

Environmental factors are largely responsible for the value of property. Man's attitude towards the surrounding environment is not neutral because humans search for locations that deliver a high quality of life. Those expectations particularly concern man's daily surroundings, including residential areas or recreational grounds. The quality of that environment largely affects the decisions made in real estate market. This factor influences the value of property, and its social popularity generates economic benefits (Cellmer, Senetra \& Szczepanska, 2012). Earlier study by Simons, Bowen and Sementelli (1997) and Brasington (1999) used ordinal values to measure the impact of environmental variables on house values.

Makropoulos, (2006) considers urban and suburban green, lakes, rivers and sea, topography as far as green areas, wetlands and mountain areas as the most important influential environmental factors. The benefit from these elements are numerous, some of which are the stabilization of the global and local climate, the decrease of flood events, the enrichment of the ecosystems etc. (Morancho, 2003; Xatzibiros, 2007). On the other hand, risk of natural disasters can certainly influence negatively real estate market values

Nikolaos, Dimitra and Agapi (2011) hinted that the market value of a real estate is affected strongly by environmental factors among others. There is also a growing body of research into the influence of environmental pollution on living conditions in urban areas. Earlier study by Lake, Lovett, Bateman and Langford (1998) assigned monetary value to the negative impacts of road development, specifically noise and visual intrusion.

From the human ecology perspective, the natural environment influences housing choice. As a result of human interaction with environmental components such as land, water, air, land cover and other natural resources (Garrod \& Willis, 1994). Research from Kohlhase, 1991, and several other authors shows that toxic or hazardous waste site is a function of worth of a real estate value. Other authors have analyzed the applicability of Geographic Information Systems for assessing the impact of noise on property prices (Trojanek, 2013).

Further research by Garrod and Wills (1994), Boyle and Kiel (2001) and Jim and Chen (2006) have been carried out studies on the impact of environmental amenity on house prices. Environmental factors that adversely influences residential property values is shown in Fig. 1.

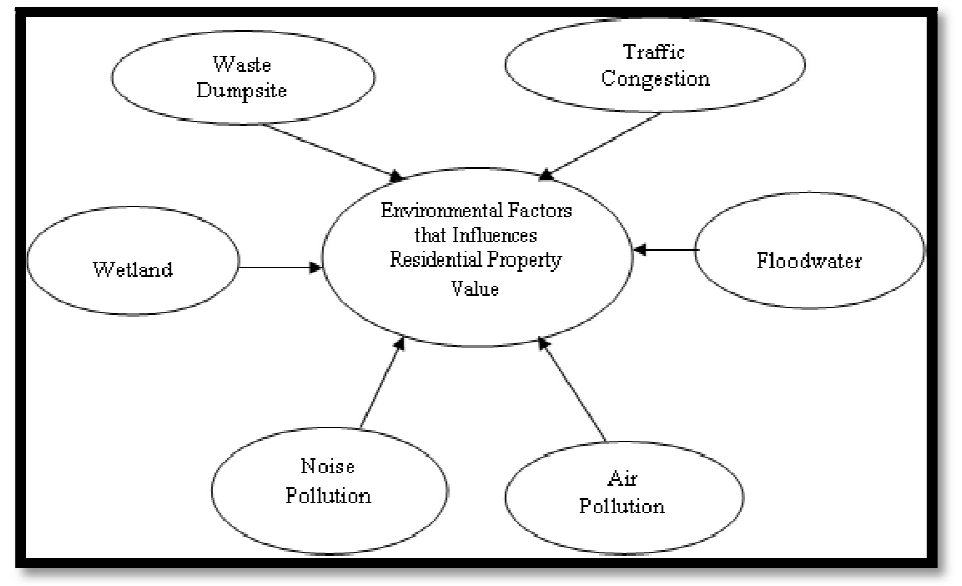

Figure 1: Model of Environmental Factors Adversely Influences Residential Property Values

Source: Author's Work, 2019

\section{Materials and Methods}

\subsection{Purpose of the Study}

The purpose of this study is to assess the relationship between environmental variables and rental value of residential properties in Greater Port Harcourt City, Rivers State. 


\subsection{Research Questions}

- What are the environmental factors that negatively influence residential property value in Greater Port Harcourt City?

- To what extent does environmental factors negatively influence residential property value in Greater Port Harcourt City?

- What is the correlation between environmental variables and rental value of residential properties in Greater Port Harcourt City?

\subsection{Research Hypothesis}

- $\mathrm{HO}_{1}$ : There is no correlation between environmental variables and rental value of residential properties in Greater Port Harcourt City.

\subsection{The Study Area}

Greater Port Harcourt City is a metropolitan area currently under construction in Rivers State, Nigeria. It is a modern, well planned and consciously developed city that will not only decongest the already over-populated city of Port Harcourt, the Rivers State Capital, but a one that will lay a solid foundation for infrastructural explosion with the highest economic potentials and become the hub of business activities not only in the hydro carbon industry but also in the tourism sector of the nation's economy.

Rivers State of Nigeria where the city of Port Harcourt is situated comprises twenty-three (23) Local Government Areas, while the Greater Port Harcourt City extends over eight (8) of them, these eight (8) Local Government Areas are: Port Harcourt Local Government Area, the most southern Local Government Area; Oyigbo, Eleme, Okrika and Ogu-Bolo Local Government Areas situated to the east and south of the central business district (CBD); Obio/Akpor directly to the north of Port Harcourt Local Government Area; Ikwerre Local Government Area to the north-west of Obio/Akpor Local Government Area; and Etche Local Government Area to the north-east which includes the Otamiri-Etche River. Greater Port Harcourt does not completely encase all eight Local Government Areas. In most instances, only sections or fractions of the Local Government Areas form part of the urban agglomeration which is known as Greater Port Harcourt City. The expanded City covers an area of approximately 1900sq. km (Fig. 2) and houses over two (2) million people, who live in conditions of informal shelters and high densities. The actual land area left to accommodate the New City is approximately 40 000ha (Ede, Owei and Akarolo, 2011).

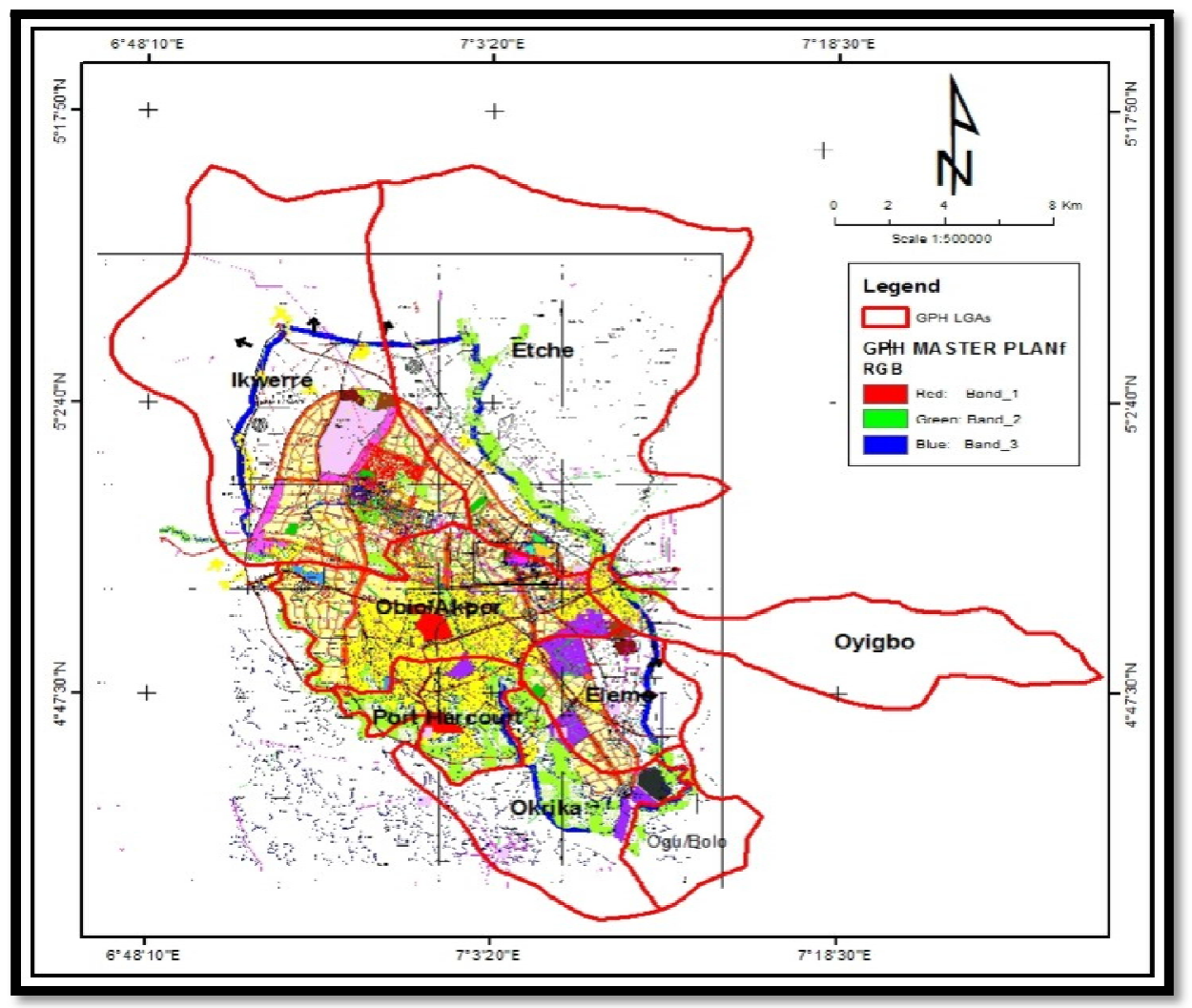

Figure 2: Map of the Study Area, Greater Port Harcourt City, Rivers State, Nigeria Source: GPHC Master Plan - Office of the Surveyor General Rivers State, (2019)

\subsection{Statistical Analysis}

This study employed the non-experimental design which describe phenomena and examine relationships between phenomena without any direct manipulation of conditions that are experienced. Hence, the correlational design was adopted. Nwogu (1991) defined correlational design as the type of study that seeks to establish what relationship exists between two or more variables. Usually such studies indicate the direction and magnitude of the relationship 
between the variables. The study is correlational because the researcher gathered two sets of data (scores) from the respondents. The two sets of questionnaires (Residents and Estate Surveyors) were used to obtain data from the respondents. Finally, the two sets of scores were correlated to determine the relationship between environmental variables and rental value of residential properties. The population of the study was 2,637,285 residents of Greater Port Harcourt City (National Population Commission, 2006) from which a sample of 616 respondents (500 residents and 116 professional Estate Surveying \& Valuation Firms) were selected. According to Nigerian Institution of Estate Surveyors \& Valuers Directory (NIESV, 2019), there are One Hundred \& Sixteen (116) Estate Surveying \&Valuation Firms in Port Harcourt (Rivers State) Metropolis. Data for the study was collected from both primary and secondary sources. Secondary data was collected from past studies in the study area of the research interest. The primary data was obtained from Practicing Estate Surveying \& Valuation Firms and Residents of Greater Port Harcourt City; while personal interview was conducted on them respectively. The major instrument for data collection was the questionnaire. The researcher used both descriptive and inferential statistical tools to analyze the data gotten from the field. The descriptive tools used includes frequency distribution tables, charts, mean and standard deviation, while the inferential tools used in analyzing hypothesis includes Spearman Rank Correlation.

\section{Results and Discussion}

Tables 1 and 2 summaries the residents and estate valuer's perception on the environmental variables that negatively influences residential property value in Greater Port Harcourt City.

\begin{tabular}{|c|c|c|c|c|c|c|c|c|c|}
\hline $\mathrm{S} / \mathrm{N}$ & Items & 6 & 5 & 4 & 3 & 2 & 1 & Mean & $\begin{array}{c}\text { Standard } \\
\text { Deviation } \\
\end{array}$ \\
\hline 1 & $\begin{array}{c}\text { Traffic congestion } \\
\text { (Poor Road } \\
\text { Network) } \\
\end{array}$ & $\begin{array}{c}59 \\
(13.1 \%)\end{array}$ & $\begin{array}{c}62 \\
(13.8 \%)\end{array}$ & $\begin{array}{c}43 \\
(9.6 \%)\end{array}$ & $\begin{array}{c}104 \\
(23.1 \%)\end{array}$ & $\begin{array}{c}47 \\
(10.4 \%)\end{array}$ & $\begin{array}{c}135 \\
(30 \%)\end{array}$ & 3.06 & 1.7705 \\
\hline 2 & Floodwater & $\begin{array}{c}225 \\
(50 \%)\end{array}$ & $\begin{array}{c}104 \\
(23.1 \%)\end{array}$ & $\begin{array}{c}46 \\
(10.2 \%)\end{array}$ & $\begin{array}{c}15 \\
(3.3 \%)\end{array}$ & $\begin{array}{c}44 \\
(9.8 \%)\end{array}$ & $\begin{array}{c}16 \\
(3.6 \%)\end{array}$ & 4.90 & 1.4759 \\
\hline 3 & Air pollution & $\begin{array}{c}89 \\
(19.8 \%) \\
\end{array}$ & $\begin{array}{c}61 \\
(13.6 \%) \\
\end{array}$ & $\begin{array}{c}136 \\
(30.2 \%) \\
\end{array}$ & $\begin{array}{c}60 \\
(13.3 \%) \\
\end{array}$ & $\begin{array}{c}104 \\
(23.1 \%) \\
\end{array}$ & $\begin{array}{c}0 \\
(0 \%)\end{array}$ & 3.94 & 1.4088 \\
\hline 4 & Waste Dumpsite & $\begin{array}{c}60 \\
(13.3 \%) \\
\end{array}$ & $\begin{array}{c}149 \\
(33.1 \%) \\
\end{array}$ & $\begin{array}{c}61 \\
(13.6 \%) \\
\end{array}$ & $\begin{array}{c}89 \\
(19.8 \%) \\
\end{array}$ & $\begin{array}{c}57 \\
(12.7 \%) \\
\end{array}$ & $\begin{array}{c}34 \\
(7.6 \%) \\
\end{array}$ & 3.92 & 1.4992 \\
\hline 5 & Noise Pollution & $\begin{array}{c}30 \\
(6.7 \%)\end{array}$ & $\begin{array}{c}45 \\
(10 \%)\end{array}$ & $\begin{array}{c}29 \\
(6.4 \%)\end{array}$ & $\begin{array}{c}136 \\
(30.2 \%)\end{array}$ & $\begin{array}{c}59 \\
(13.1 \%)\end{array}$ & $\begin{array}{c}151 \\
(33.6 \%)\end{array}$ & 2.66 & 1.5586 \\
\hline 6 & Wetland & $\begin{array}{c}29 \\
(6.4 \%) \\
\end{array}$ & $\begin{array}{c}16 \\
(3.6 \%) \\
\end{array}$ & $\begin{array}{c}43 \\
(9.6 \%) \\
\end{array}$ & $\begin{array}{c}107 \\
(23.8 \%) \\
\end{array}$ & $\begin{array}{c}164 \\
(36.4 \%) \\
\end{array}$ & $\begin{array}{c}91 \\
(20.2 \%) \\
\end{array}$ & 2.59 & 1.3520 \\
\hline
\end{tabular}

Table 1: Mean and Standard Deviation on Environmental Variables That Negatively Influences Residential Property Value in Greater Port Harcourt City (Resident's Perception)

Source: Author's Field Survey, January, 2020

\begin{tabular}{|c|c|c|c|c|c|c|c|c|c|}
\hline S/N & Items & 6 & 5 & 4 & 3 & 2 & 1 & Mean & SD \\
\hline 1 & $\begin{array}{c}\text { Traffic } \\
\text { congestion } \\
\text { (Poor Road } \\
\text { Network) } \\
\end{array}$ & $\begin{array}{c}35 \\
(44.9 \%)\end{array}$ & $\begin{array}{c}29 \\
(37.1 \%)\end{array}$ & $\begin{array}{c}7 \\
(9 \%)\end{array}$ & $\begin{array}{c}7 \\
(9 \%)\end{array}$ & $\begin{array}{c}0 \\
(0 \%)\end{array}$ & $\begin{array}{c}0 \\
(0 \%)\end{array}$ & 5.16 & 0.9388 \\
\hline 2 & Floodwater & $\begin{array}{c}54 \\
(69.2 \%) \\
\end{array}$ & $\begin{array}{c}12 \\
(15.4 \%) \\
\end{array}$ & $\begin{array}{c}6 \\
(7.7 \%) \\
\end{array}$ & $\begin{array}{c}6 \\
(7.7 \%) \\
\end{array}$ & $\begin{array}{c}0 \\
(0 \%)\end{array}$ & $\begin{array}{c}0 \\
(0 \%) \\
\end{array}$ & 5.45 & 0.9437 \\
\hline 3 & Air pollution & $\begin{array}{c}42 \\
(53.8 \%)\end{array}$ & $\begin{array}{c}6 \\
(7.7 \%) \\
\end{array}$ & $\begin{array}{c}12 \\
(15.4 \%)\end{array}$ & $\begin{array}{c}12 \\
(15.4 \%)\end{array}$ & $\begin{array}{c}6 \\
(7.7 \%)\end{array}$ & $\begin{array}{c}0 \\
(0 \%)\end{array}$ & 4.82 & 1.4209 \\
\hline 4 & Waste Dumpsite & $\begin{array}{c}48 \\
(61.5 \%)\end{array}$ & $\begin{array}{c}6 \\
(7.7 \%) \\
\end{array}$ & $\begin{array}{c}6 \\
(7.7 \%) \\
\end{array}$ & $\begin{array}{c}12 \\
(15.4 \%)\end{array}$ & $\begin{array}{c}6 \\
(7.7 \%) \\
\end{array}$ & $\begin{array}{c}0 \\
(0 \%)\end{array}$ & 4.97 & 1.4327 \\
\hline 5 & Noise Pollution & $\begin{array}{c}35 \\
(44.9 \%) \\
\end{array}$ & $\begin{array}{c}26 \\
(33.3 \%) \\
\end{array}$ & $\begin{array}{c}12 \\
(15.4 \%) \\
\end{array}$ & $\begin{array}{c}0 \\
(0 \%) \\
\end{array}$ & $\begin{array}{c}0 \\
(0 \%)\end{array}$ & $\begin{array}{c}5 \\
(6.4 \%) \\
\end{array}$ & 5.01 & 1.2909 \\
\hline 6 & Wetland & $\begin{array}{c}35 \\
(44.9 \%)\end{array}$ & $\begin{array}{c}26 \\
(33.3 \%) \\
\end{array}$ & $\begin{array}{c}7 \\
(9.0 \%)\end{array}$ & $\begin{array}{c}5 \\
(6.4 \%)\end{array}$ & $\begin{array}{c}0 \\
(0 \%)\end{array}$ & $\begin{array}{c}5 \\
(6.4 \%)\end{array}$ & 4.95 & 1.3652 \\
\hline
\end{tabular}

Table 2: Mean and Standard Deviation on Environmental Variables That Negatively

Influences Residential Property Value in Greater Port Harcourt City (Estate Valuer's Perception) Source: Author's Field Survey, January 2020

In the course of examining the environmental variables that negatively influence residential property value in the study area, the respondents were asked if they are of the opinion that environmental variables affect residential property value. The result revealed that $80.2 \%$ (i.e. 361 out of 450 ) of the residents (respondents) are of the opinion that environmental variables have negative influence on residential property value in Greater Port Harcourt City; while 69.2\% (i.e. 54 out of 78) of the Estate Valuers (respondents) also agreed that environmental variables have negative influence on residential property value in the study area. This conforms to the fact that the quality of environment largely affects the 
decisions made in real estate market. These variables influence the value of property, and its social popularity generates economic benefits (Cellmer, Senetra and Szezepanska, 2012).

In an attempt to examine the possible environmental variables that negatively affect residential property value in Greater Port Harcourt City. Table 1 and 2 revealed that the respondents (Resident's Mean $=4.90$, SD $=1.4759$ and Estate Valuer's Mean $=5.45, \mathrm{SD}=0.9437$ ) agreed that flood water among all other variables has the greatest negative effect on residential property value. In justification of the above, Figure 1 showed the level of flood water and some residential properties affected by flood water at Okomoko Street D/Line, Port Harcourt; while Figure 2 revealed residential neighbourhood characterized with flood water at Akwaka Road Rumuodamaya in Obio-Akpor Local Government Area.

The respondents rated air pollution (Mean $=3.94, \mathrm{SD}=1.4088$ ) as the second environmental variables that negatively affect residential property value in Greater Port Harcourt City as shown on Table 1 . Figure s 3 and 4 showed a residential property that has been in void state for a period of five years as a result of its proximity to a cooking Gas refilling station at Rumuodamaya in Obio-Akpor LGA in Rivers State confirmed the respondent's view.

The third rated environmental variables that has negative effect on residential property value in Greater Port Harcourt City as shown in Table 1 is waste dumpsite (Mean $=3.92$, SD $=1.4992$ ). Figure 5 showed residential property affected by proximity to waste dumpsite at Elikpokwu-udo, Obio-Akpor Local Government Area in Rivers State. Investigation revealed that the proximity to waste dumpsite has resulted to depreciation in property value. A decent and quality environment cannot be over-emphasized in terms of its relation to residential property value.

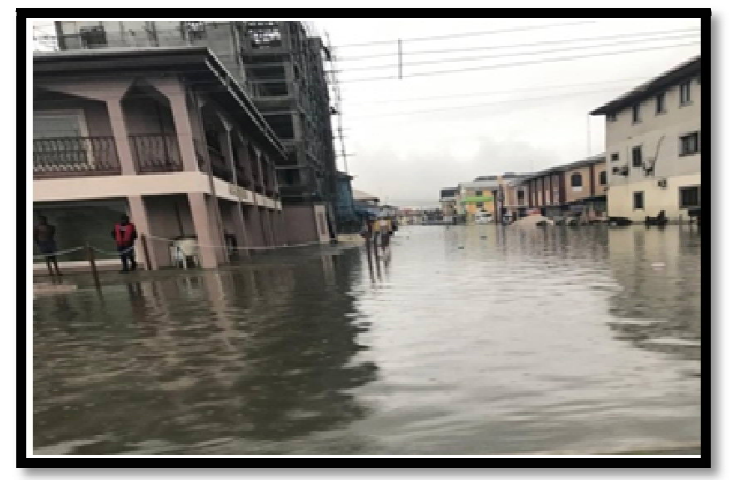

Figure 3: Residential Properties Affected by Flood Water at Okomoko Street, D/Line Port Harcourt

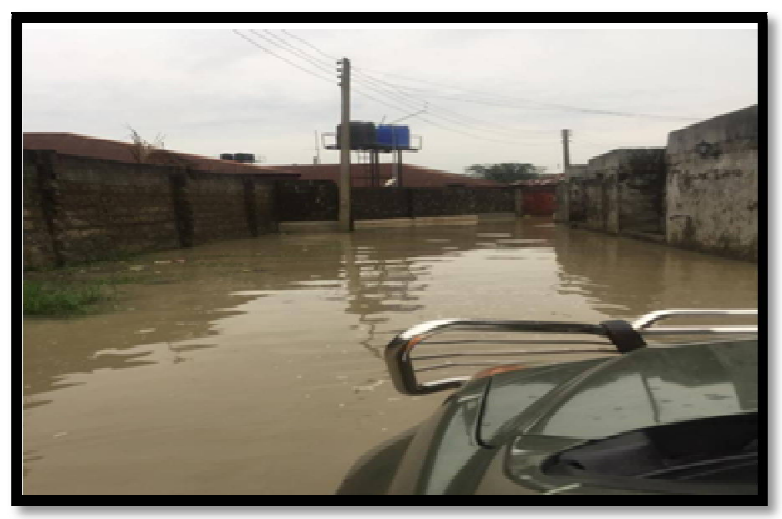

Figure 4: Residential Neighbourhood Characterized with Flood Water at Akwaka Road, Rumuodamaya Obio-Akpor LGA

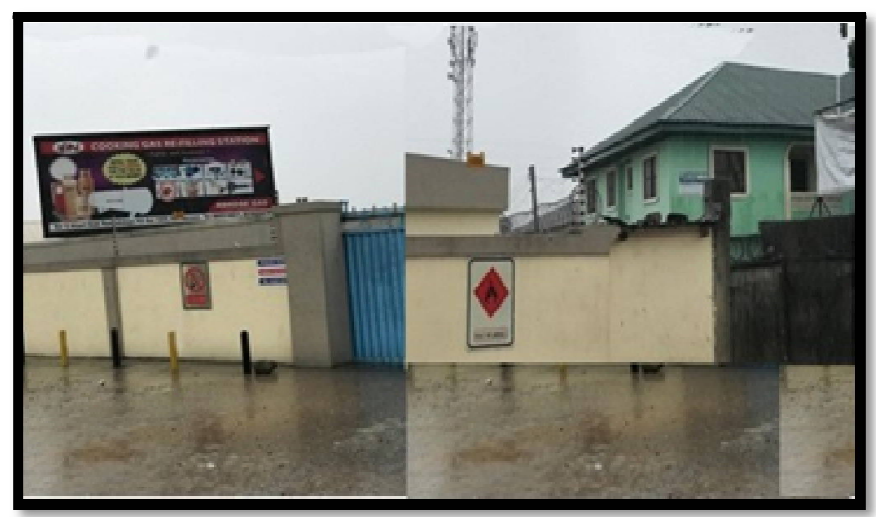

Figure 5: Residential Property Situated Close to Gas Re-Filling Station 


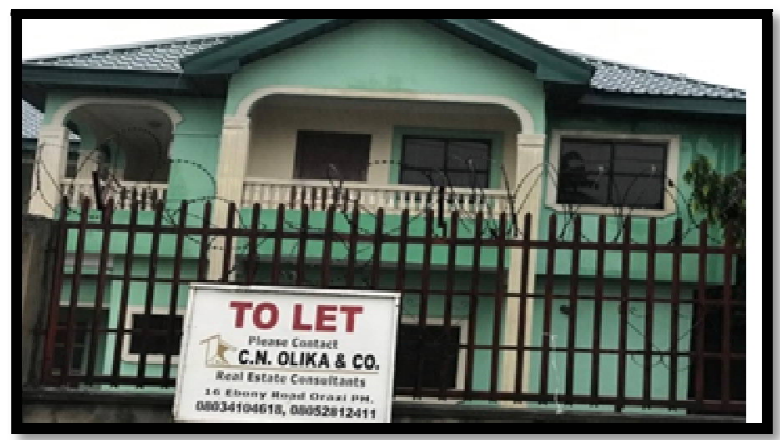

Figure 6: Residential Property in Void State Due to Air Pollution as a Result of Its Proximity to Gas Re-Filling Station at Rumuodumaya, Obio-Akpor LGA

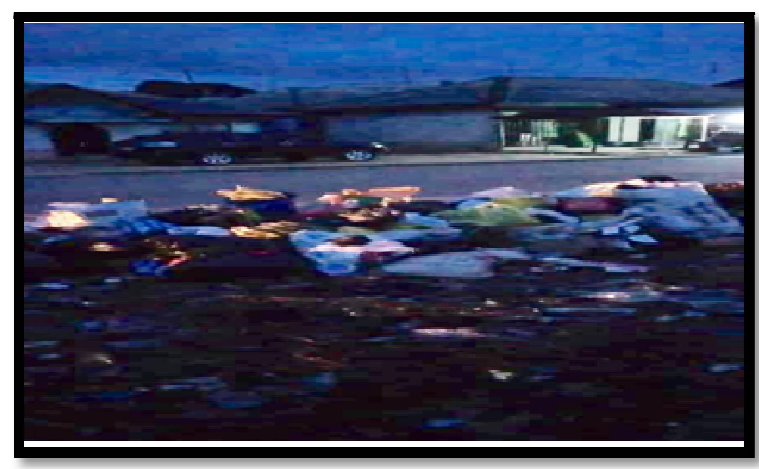

Figure 7: Residential Property Affected by Proximity to Waste Dumpsite at Elikpokwu-Udo, Obio-Akpor LGA

Table 3 and 4 presents rental value of residential properties and the result of Individual Contributions of location factors on residential property value (Estate Valuer's Perception) in Greater Port Harcourt City respectively.

\begin{tabular}{|c|c|c|c|c|}
\hline $\mathbf{S} / \mathbf{N}$ & Local Government Area & Town & $\begin{array}{c}\text { Rental Value of } \\
\text { Two (2) Bedroom } \\
\text { Flat }\end{array}$ & $\begin{array}{l}\text { Rental Value of Self- } \\
\text { Contained }\end{array}$ \\
\hline \multirow[t]{2}{*}{1} & \multirow[t]{2}{*}{ Ikwerre } & Igwuruta - Ali & $250,000.00$ & $120,000.00$ \\
\hline & & Aluu & $200,000.00$ & $100,000.00$ \\
\hline \multirow[t]{2}{*}{2} & \multirow[t]{2}{*}{ Etche } & Igbo Etche & $400,000.00$ & $150,000.00$ \\
\hline & & Odogwa & $80,000.00$ & $40,000.00$ \\
\hline \multirow[t]{2}{*}{3} & \multirow[t]{2}{*}{ Obio-Akpor } & Rukpokwu & $350,000.00$ & $150,000.00$ \\
\hline & & Ozuoba & $550,000.00$ & $250,000.00$ \\
\hline \multirow[t]{2}{*}{4} & \multirow[t]{2}{*}{ Port Harcourt } & Odili Road, Abuloma & $800,000.00$ & $300,000.00$ \\
\hline & & Rumukalagbor & $400,000.00$ & $200,000.00$ \\
\hline \multirow[t]{2}{*}{5} & \multirow[t]{2}{*}{ Eleme } & Onne & $300,000.00$ & $200,000.00$ \\
\hline & & Eteo & $180,000.00$ & $120,000.00$ \\
\hline \multirow[t]{2}{*}{6} & \multirow[t]{2}{*}{ Oyigbo } & Izuoma & $180,000.00$ & $90,000.00$ \\
\hline & & Oyigbo Town & $350,000.00$ & $150,000.00$ \\
\hline \multirow[t]{2}{*}{7} & \multirow[t]{2}{*}{ Okrika } & Okujagu & $450,000.00$ & $200,000.00$ \\
\hline & & Kalio & $250,000.00$ & $100,000.00$ \\
\hline \multirow[t]{2}{*}{8} & \multirow[t]{2}{*}{ Ogu/Bolo } & Ogu town & $150,000.00$ & $80,000.00$ \\
\hline & & Agokien & $80,000.00$ & $30,000.00$ \\
\hline
\end{tabular}

Table 3: Rental Value of Residential Properties in Greater Port Harcourt City Source: Author's Field Survey, January, 2020 


\begin{tabular}{|c|c|c|c|c|c|c|c|c|}
\hline $\mathbf{S} / \mathbf{N}$ & Items & SA & $\mathbf{A}$ & $\mathbf{N}$ & $\mathbf{D}$ & SD & Mean & SD \\
\hline 1 & $\begin{array}{c}\text { Flood-water reduces residential } \\
\text { property value. }\end{array}$ & $\begin{array}{c}33 \\
(43.4 \%)\end{array}$ & $\begin{array}{c}34 \\
(44.7 \%)\end{array}$ & $\begin{array}{c}0 \\
(0 \%)\end{array}$ & $\begin{array}{c}9 \\
(11.8 \%)\end{array}$ & $\begin{array}{c}0 \\
(0 \%)\end{array}$ & 4.20 & 0.9384 \\
\hline 2 & $\begin{array}{c}\text { Proximity to waste dump sites } \\
\text { increases demand for residential } \\
\text { property. }\end{array}$ & $\begin{array}{c}29 \\
(38.2 \%)\end{array}$ & $\begin{array}{c}12 \\
(15.8 \%)\end{array}$ & $\begin{array}{c}0 \\
(0 \%)\end{array}$ & $\begin{array}{c}35 \\
(46.1 \%)\end{array}$ & $\begin{array}{c}0 \\
(0 \%)\end{array}$ & 3.46 & 1.3994 \\
\hline 3 & $\begin{array}{c}\text { High volume of vehicular } \\
\text { movement and traffic increases } \\
\text { demand for residential property }\end{array}$ & $\begin{array}{c}0 \\
(0 \%)\end{array}$ & $\begin{array}{c}40 \\
(52.6 \%)\end{array}$ & $\begin{array}{c}5 \\
(6.6 \%)\end{array}$ & $\begin{array}{c}26 \\
(34.2 \%)\end{array}$ & $\begin{array}{c}5 \\
(6.6 \%)\end{array}$ & 3.05 & 1.0696 \\
\hline 4 & $\begin{array}{c}\text { Increased level of carbon } \\
\text { emission in the air discourages } \\
\text { demand for residential property. }\end{array}$ & $\begin{array}{c}27 \\
(35.5 \%)\end{array}$ & $\begin{array}{c}29 \\
(38.2 \%)\end{array}$ & $\begin{array}{c}12 \\
(15.8 \%)\end{array}$ & $\begin{array}{c}8 \\
(10.5 \%)\end{array}$ & $\begin{array}{c}0 \\
(0 \%)\end{array}$ & 3.99 & 0.9729 \\
\hline
\end{tabular}

Table 4: Mean and Standard Deviation on the Individual Contributions of Location Factors on Residential Property Value (Estate Valuer's Perception)

Source: Author's Field Survey, January, 2020

The study revealed Estate Valuer's perception on individual contribution of location factors on residential property value. Most residents highlighted that they are faced with problem of flooding and they agreed that flood water reduces residential property value in their neighbourhood. The environmental attributes of a given location are very necessary and also have a great influence on residential property Value. No prospective occupiers will like to live in a flooded neighbourhood because it poses threat to both human beings and properties as well.

The Estate Surveyors disagreed that proximity to waste dumpsites increases demand for residential properties. This indicates that most residents are aware of the danger in living close to a waste dumpsite and the health implication of hazardous waste on man and the environment. They agreed that increased vehicular movement (i.e. traffic congestion) increases demand for residential properties.

The study showed that the respondents further agreed that increased level of carbon emission in the air discourages demand for residential property. It is unsafe to live in a polluted environment and nobody will like to rent a property located in such neighbourhood. It was observed in the course of this research (Figure 4) that residential property situated in polluted neighbourhood rarely exchange hand in open market and usually characterized with depreciation in value.

\subsection{Test of Hypothesis}

- $\mathrm{Ho}_{1}$ : There is no Correlation between Environmental variables and rental value of residential properties in Greater Port Harcourt City.

\begin{tabular}{|c|c|c|c|c|}
\hline & & & $\begin{array}{c}\text { Rating of } \\
\text { Environment } \\
\text { al Variables }\end{array}$ & $\begin{array}{c}\text { Rental Value of } \\
\text { Residential } \\
\text { Properties }\end{array}$ \\
\hline \multirow[t]{6}{*}{$\begin{array}{c}\text { Spearman's } \\
\text { rho }\end{array}$} & \multirow{3}{*}{$\begin{array}{c}\text { Rating of } \\
\text { environmental } \\
\text { variables }\end{array}$} & $\begin{array}{l}\text { Correlation } \\
\text { Coefficient }\end{array}$ & 1.000 & $.435^{* *}$ \\
\hline & & Sig. (2-tailed) & . & .001 \\
\hline & & $\mathrm{N}$ & 450 & 450 \\
\hline & \multirow{3}{*}{$\begin{array}{l}\text { Rental value of } \\
\text { residential } \\
\text { properties }\end{array}$} & $\begin{array}{c}\text { Correlation } \\
\text { Coefficient }\end{array}$ & $.435^{* *}$ & 1.000 \\
\hline & & Sig. (2-tailed) & .001 & . \\
\hline & & $\mathrm{N}$ & 450 & 450 \\
\hline
\end{tabular}

Table 5: Correlation between Environmental Variables and Rental Value of Residential Properties in Greater Port Harcourt City

**. Correlation Is Significant at the 0.01 Level (2-Tailed)

Spearman correlations was conducted in order to determine if there was a relationship (association) between rating of environmental variables in Greater Port Harcourt City and rental value of residential properties. A two-tailed test of significance using Spearman's correlation indicated a statistically significant relationship between both variables; (450) $=.435, \mathrm{p}<.001$.

The test of significance indicated that with $\mathrm{p}<.001$, we can reject the null hypothesis which stated that there is no correlation between environmental variables and rental value of residential properties in Greater Port Harcourt City and accept the alternative hypothesis which states that there is correlation between environmental variables and rental value of residential properties in Greater Port Harcourt City. Findings as presented in Table 5 showed that there is a reliable relationship between environmental variables and rental value of residential properties in the study area.

The environmental variables considered in this study include air pollution, flood water, noise pollution, wetland, waste dumpsite and traffic congestion (poor road network). Mean and standard deviation analysis was used to determine the critical environmental variables that exert more influence on residential property value in the study area. The study 
revealed that flooding, air pollution and waste dumpsite (poor waste management) are the most critical environmental variables that negatively influence residential property value.

Findings also revealed that residential properties situated in less desired areas characterized with environmental problems like flooding, air pollution and waste dumpsite (poor waste management) and other environmental disamenities command low market values while others located in a fully developed environmentally friendly neighbourhood characterized with adequate infrastructural facilities command high market value. This provides support to findings of prior studies on factors that affect residential property value generally. Investigation revealed that some residential properties in Greater Port Harcourt City are in dilapidated and void state due to environmental problems.

Interview conducted with the Professional Estate Valuers, revealed that many of the residential properties in their management portfolio has been in void state and could not be renovated because prospective tenants are not interested in renting properties in such areas due to frequent flooding and air pollution issues. It was also observed that flooding is a common occurrence in the city; it is not caused by overflow of riverbanks or creeks but by rain falling on the impervious surface of the urban terrain, inadequate drainage system, disregarding of flood policy especially in building on flood prone areas.

Ironically, Greater Port Harcourt City Authority that is charged with the responsibility of developing the new city are not ensuring strict adherence to full implementation of the city's development master plan. This situation was taken into consideration while proffering solution to the problem.

\section{Conclusion}

It has been established that there is a relationship between environmental variables and rental values of residential properties situated in Greater Port Harcourt City. Flood water, air pollution and waste dumpsite are known major environmental variables that negatively affect rental values of residential properties.

\section{Recommendation}

The following recommendations are put forward as reduction and control measure to mitigate the negative effects of environmental variables on rental value of residential properties.

- Strategic environmental education and policies should be inculcated into our national education systems.

- Need to create public awareness to facilitate the transmission of environmental information in order to promote more positive environmental attitudes that will reduce the negative effects.

- $\quad$ Construction of good drainage system, adoption of proper waste management disposal system including waste recycling and other measures that enhance good standard of living and higher environmental standards.

- Top level government officials, politicians, administrators and major developers should properly orientate on environmental related issues.

- Revival of the Greater Port Harcourt City Development Authority that is charged with the responsibility for the implementation of Greater Port Harcourt City Master plan.

\section{References}

i. AFRES, (2017). African Real Estate Society 17th Conference on Land Acquisition for Residential Property; LUMBAGO for Private Real Estate Developer, Lagos, Nigeria.

ii. Ajibola, M. O, Olaniyan, M. A \& Simon, R. F. (2012). Assessing the Effects of Urban Planning on Residential Property Values in Agege, Lagos 8(11).

iii. Ayotamuno, A. \& Owei, O.B. (2015). Housing in Port Harcourt, Nigeria: The Modified Building Approval Process. Environmental and Sustainable Development,4(1), 16 - 27.

iv. Brasington, D.M. (1999). Which Measures of School Quality Does the Housing Market Value? Journal of Real Estate Research, 18, 395-413.

v. Boyle, M. A. \& Kiel, K. A. (2001). "A Survey of House Price Hedonic Studies of the Impact of Environmental Externalities". Journal of Real Estate Literature 9, 117-144.

vi. Cellmer, R., Senetra, A. \& Szczepańska, A. (2012). The Effect of Environmental Factors on Property Value, (paper presented at the FIG Working Week 2012 TS06H - Valuation - Environmental Factors 5748, Rome, Italy), www.fig.net (access may, 2019.)

vii. Ede, P. N., Owei, O. B. \& Akarolo, C. I. (2011). Does the Greater Port Harcourt 2008 meet aspirations for liveable City? Paper presented on the $47^{\text {th }}$ Congress of the International Society of City and Regional Planners. Liveable Cities: Urbanizing World, Meeting the Challenges. Wuhan. Retrieved from http://www.isocarp-.net/Datacase _studies/1859.pdf.

viii. Ekenta, C. (2010). Infrastructures Provision on Real Property Values: A comparative Study of Agbama and Housing Estate, Ehimiri Umuahia, Nigeria. International Journal of Environment, Ecology, Family and Urban Studies, 4, $9-20$.

ix. Garrod, G. \& Willis, K. (1994). An Economic Estimate of the Effect of a Waterside Location on Property Values; Environmental and Resource Economics, 4, 209 - 217.

X. GE, X. J. \& Du, Y. (2007). Main Variables Influencing Residential Property Values Using the Entropy Method The Case of Auckland. Paper Presented at the Proceedings of the $5^{\text {th }}$ International Structural Engineering and Construction Conference. Shunan, Japan.

xi. Jim, C. Y. \& Chen, W.Y. (2009). Value of Scenic Views: Hedonic Assessment of Private Housing in Hong Kong. Landscape and Urban Planning

xii. 91(4), 226-234. 
xiii. Kohlhase, J. (1991). The Impact of Toxic Waste Sites on Housing Values. Journal of Urban Economics, 30, 1 - 26.

xiv. Lake, I. R., Lovett, A. A., Bateman, I. J. \& Langford, I. H. (1998). Modeling environmental influences on property prices in an urban environment, Compute Environ. and Urban Systems, 22(2), 121 - 136.

xv. Leramo, G. A. (1992). The Groundwork of Property Valuation. Kaduna Polytechnic Press, Kaduna.

xvi. Makropoulos, K. (2006). Natural disasters: Earthquakes and protection measures, (Paper presented at the $15^{\text {th }}$ Conference of Concrete, Alexandroupolis).

xvii. Millington, A. F. (1981). Introduction to Property Valuation. London the Gazette Nigerian Institution of Estate Surveyors and Valuers (NIESV, 2009). Directory of Members and Registered Firms, 7th Edition.

xviii. Morancho, B. A. (2003). A hedonic valuation of urban green areas, Landscape and urban planning, 66, 35 -41 .

xix. National Population Commission (2006). Population Census of the Federal Republic of Nigeria.

xx. Nigerian Institute of Estate Survey \&Valuers (2019). Rivers State Chapter.

xxi. Nikolaos, K., Dimitra .V. \& Agapi, .X. (2011). Real Estate Values and Environment: A case Study on the Environment on Residential Real Estates Value. International Journal of Academic Research, 3(1), 861 - 868.

xxii. Nwogu, B. G. (1991). Educational Research: Basic Issues and Methodology. Wisdom Publishers, Ibadan.

xxiii. Nwuba, C. C. (2004). An Analysis of Location Differences in Trends in House Rents in Kaduna Nigeria. Journal of the Nigerian Institution of Estate Surveyors and Valuers, 2(1),

xxiv. Olusegun, G. K., 2003. Principles and Practice of Property Valuation, General Principles, Climax Communications Limited, Lagos.

xxv. Segerson, K. (2001). Real Estate and the Environment: An Introduction. Journal of Real Estate Finance and Economics, 22(23), 135-139.

xxvi. Trojanek, M. (2013). Customer Behavior Patterns on the Primary Housing Market in Poznan in the Period 2010-2011.Real Estate Management and Valuation, 21(4), 47 - 53.

xxvii. Xatzibiros, K. (2007). Ecology: Ecosystems and protection of the environment, (Athens: Symmetry publications) 